\title{
Transient tracer distributions in the Fram Strait in 2012 and inferred anthropogenic carbon content and transport
}

\author{
Tim Stöven ${ }^{1}$, Toste Tanhua ${ }^{1}$, Mario Hoppema ${ }^{2}$, and Wilken-Jon von Appen ${ }^{2}$ \\ ${ }^{1}$ Helmholtz Centre for Ocean Research Kiel, GEOMAR, Kiel, Germany \\ ${ }^{2}$ Alfred Wegener Institute Helmholtz Centre for Polar and Marine Research, Bremerhaven, Germany \\ Correspondence to: Tim Stöven (tstoeven@geomar.de)
}

Received: 5 August 2015 - Published in Ocean Sci. Discuss.: 24 September 2015

Revised: 12 January 2016 - Accepted: 3 February 2016 - Published: 25 February 2016

\begin{abstract}
The storage of anthropogenic carbon in the ocean's interior is an important process which modulates the increasing carbon dioxide concentrations in the atmosphere. The polar regions are expected to be net sinks for anthropogenic carbon. Transport estimates of dissolved inorganic carbon and the anthropogenic offset can thus provide information about the magnitude of the corresponding storage processes.

Here we present a transient tracer, dissolved inorganic carbon (DIC) and total alkalinity (TA) data set along $78^{\circ} 50^{\prime} \mathrm{N}$ sampled in the Fram Strait in 2012. A theory on tracer relationships is introduced, which allows for an application of the inverse-Gaussian-transit-time distribution (IG-TTD) at high latitudes and the estimation of anthropogenic carbon concentrations. Mean current velocity measurements along the same section from 2002-2010 were used to estimate the net flux of DIC and anthropogenic carbon by the boundary currents above $840 \mathrm{~m}$ through the Fram Strait.

The new theory explains the differences between the theoretical (IG-TTD-based) tracer age relationship and the specific tracer age relationship of the field data, by saturation effects during water mass formation and/or the deliberate release experiment of $\mathrm{SF}_{6}$ in the Greenland Sea in 1996 , rather than by different mixing or ventilation processes. Based on this assumption, a maximum $\mathrm{SF}_{6}$ excess of $0.5-0.8 \mathrm{fmol} \mathrm{kg}^{-1}$ was determined in the Fram Strait at intermediate depths $(500-1600 \mathrm{~m})$. The anthropogenic carbon concentrations are $50-55 \mu \mathrm{mol} \mathrm{kg}{ }^{-1}$ in the Atlantic Water/Recirculating Atlantic Water, $40-45 \mu \mathrm{mol} \mathrm{kg}^{-1}$ in the Polar Surface Water/warm Polar Surface Water and between 10 and $35 \mu \mathrm{mol} \mathrm{kg}^{-1}$ in the deeper water layers, with lowest concentrations in the bottom layer. The net fluxes
\end{abstract}

through the Fram Strait indicate a net outflow of $\sim 0.4$ DIC and $\sim 0.01 \mathrm{PgC} \mathrm{yr}^{-1}$ anthropogenic carbon from the Arctic Ocean into the North Atlantic, albeit with high uncertainties.

\section{Introduction}

Changes in the Arctic during the last decades stand in mutual relationship with changes in the adjacent ocean areas such as the Nordic Seas, the Atlantic and the Pacific oceans. The temperature of the Atlantic Water flowing into the Arctic Ocean through the Fram Strait has warmed since 1997 (Beszczynska-Möller et al., 2012), which thus increased the heat flux into the Arctic. This has a significant influence on the perennial sea ice thickness and volume and thus on the fresh water budget (Polyakov et al., 2005; Stroeve et al., 2008; Kwok et al., 2009; Kurtz et al., 2011). The exchange and transport of heat, salt and fresh water through the major gateways like the Fram Strait, Barents Sea Opening, Canadian Archipelago and Bering Strait are also directly related to changes in ventilation of the adjacent ocean areas (Wadley and Bigg, 2002; Vellinga et al., 2008; Rudels et al., 2012). The ventilation processes of the Arctic Ocean have a significant impact on the anthropogenic carbon storage in the world ocean (Tanhua et al., 2008). Studying the fluxes of anthropogenic carbon through the major gateways contributes to understand the integrated magnitude of such ocean-atmosphere interactions. It additionally provides information of a changing environment in the Arctic Mediterranean. The required flux data of the prevailing water masses, i.e., current velocity fields, are obtained by time series of long-term maintained mooring arrays in the different gate- 
ways. The Fram Strait is the deepest gateway to the Arctic Ocean with highest volume fluxes equatorward and poleward. A well-established cross-section mooring array is located at $\sim 78^{\circ} 50^{\prime} \mathrm{N}$ in the Fram Strait (Fahrbach et al., 2001; Schauer et al., 2008) and has provided the basis for heat transport estimates in the past (Fahrbach et al., 2001; Schauer et al., 2004, 2008; Beszczynska-Möller et al., 2012). However, the current data interpretation and analysis of this mooring array is complicated due to a recirculation pattern in the Fram Strait (Schauer and Beszczynska-Möller, 2009; Rudels et al., 2008; Marnela et al., 2013; de Steur et al., 2014) and strong mesoscale eddy activity (von Appen et al., 2015a). The spatial and temporal volume flux variability and the insufficient instrument coverage in the deeper water layers, i.e., below the West Spitsbergen Current (WSC) and East Greenland Current (EGC), lead to high uncertainties of the net flux through the Fram Strait. Hence, it is the most relevant but also the most challenging gateway with respect to transport budgets in the Arctic Mediterranean.

Estimating an anthropogenic carbon budget presupposes the knowledge of the concentration ratio between the natural dissolved inorganic carbon (DIC) and anthropogenic carbon $\left(\mathrm{C}_{\mathrm{ant}}\right)$ in the water column. An estimate of DIC transport across the Arctic Ocean boundaries is provided by MacGilchrist et al. (2014), who used velocity fields by Tsubouchi et al. (2012) and available DIC data. That work provides a proper estimate of DIC fluxes, although it does not separate the specific share of anthropogenic carbon and the uncertainties are relatively high. Similarly, Jeansson et al. (2011) calculated fluxes of inorganic, organic and anthropogenic carbon to the Nordic Seas using an extensive set of carbon and transient tracer data. Here we present anthropogenic carbon column inventories in the Fram Strait using a new data set of $\mathrm{SF}_{6}$ and CFC-12 along the cross-section of the mooring array at $78^{\circ} 50^{\prime} \mathrm{N}$. The anthropogenic carbon column inventories were estimated using the transient tracers and the inverse-Gaussian-transit-time distribution (IG-TTD) model. Flux estimates of DIC and anthropogenic carbon including the Atlantic Water, Recirculating Atlantic Water, Arctic Atlantic Water and Polar Water water masses through the Fram Strait above $840 \mathrm{~m}$ are provided based on mean velocities measured with moorings between 2002 and 2010 . Common error sources and specific aspects using these tracers and this method in the Fram Strait are highlighted.

\section{Material and Methods}

\subsection{Tracer and carbon data}

A data set of CFC-12, $\mathrm{SF}_{6}$, DIC and TA was obtained during the ARK-XXVII/1 expedition from 14 June to 15 July 2012 from Bremerhaven, Germany to Longyearbyen, Svalbard on the German R/V Polarstern (Beszczynska-Möller, 2013). Figure 1 shows the stations of the zonal section along

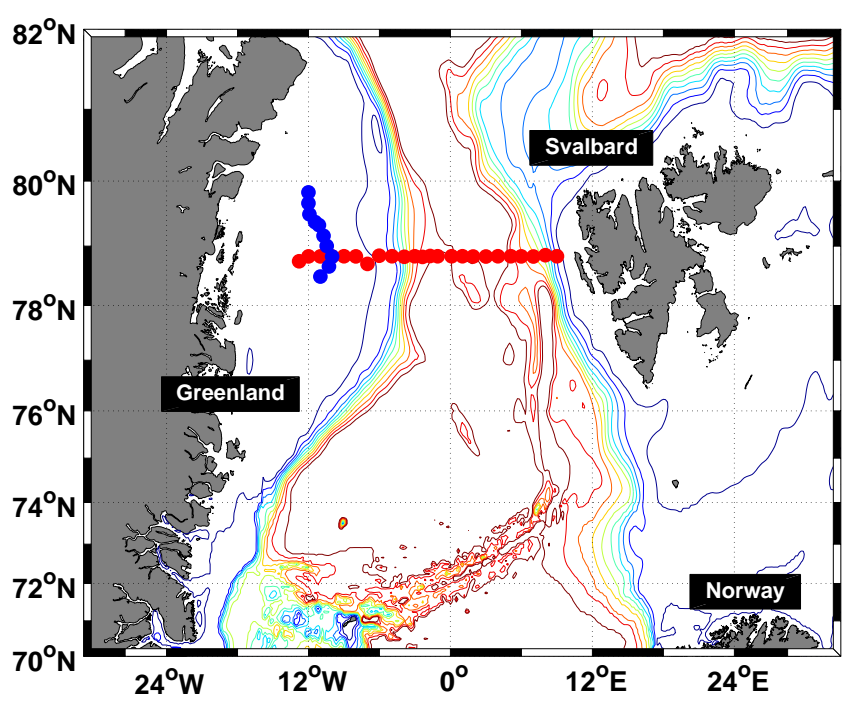

Figure 1. Sample stations of the ARK-XXVII/1 cruise in 2012. The zonal stations are highlighted as red dots and the meridional stations along the fast ice edge as blue dots. The depth contours are 250 : $250: 2500$.

$78^{\circ} 50^{\prime} \mathrm{N}$, where measurements of CFC-12, $\mathrm{SF}_{6}$, DIC and TA were conducted. The meridional section along the fast ice edge was only sampled for CFC-12 and $\mathrm{SF}_{6}$ and shows no differences in the horizontal tracer distributions compared to the corresponding longitude range of the zonal section. Therefore, we have only used the zonal section for the following analysis.

Water samples for the determination of the transient tracers $\mathrm{CFC}-12$ and $\mathrm{SF}_{6}$ were taken with $250 \mathrm{~mL}$ glass syringes and directly measured on board, using a purge and trap GC-ECD system similar to Law et al. (1994) and Bullister and Wisegarver (2008). The measurement system is identical to the PT3 system described in Stöven and Tanhua (2014) except for the cooling system and column composition. The trap consisted of a $1 / 16^{\prime \prime}$ column, packed with $70 \mathrm{~cm}$ HayeSep D and cooled to $-70^{\circ} \mathrm{C}$ during the purge process using a Dewar filled with a thin layer of liquid nitrogen. The $1 / 8^{\prime \prime}$ precolumn was packed with $30 \mathrm{~cm}$ Porasil $\mathrm{C}$ and $60 \mathrm{~cm}$ Molsieve $5 \mathrm{~A}$ and the $1 / 8^{\prime \prime}$ main column with $180 \mathrm{~cm}$ Carbograph 1AC. Due to malfunctioning of the Electron Capture Detector (ECD) of the measurement system, the samples of six stations (between station 15 and 53) were taken with $300 \mathrm{~mL}$ glass ampules and flame sealed for later onshore measurements at GEOMAR. The onshore measurement procedure is described in Stöven and Tanhua (2014). The precision for the onshore measurements is $\pm 4.4 \% / 0.09$ for $\mathrm{SF}_{6}$ and $\pm 1.9 \% / 0.09 \mathrm{pmol} \mathrm{kg}^{-1}$ for CFC-12. The precision for onboard measurements is $\pm 0.5 \% / 0.02$ for $\mathrm{SF}_{6}$ and $\pm 0.6 \% / 0.02 \mathrm{pmol} \mathrm{kg}^{-1}$ for CFC- 12 .

Water samples for DIC and total alkalinity (TA) were taken with $500 \mathrm{~mL}$ glass bottles and poisoned with $100 \mu \mathrm{L}$ of a saturated mercuric chloride solution to prevent bio- 
logical activities during storage time. The sampling procedure was carried out according to Dickson et al. (2007). The measurements of DIC and TA were performed onshore at the GEOMAR, using a coulometric measurement system (SOMMA) for DIC (Johnson et al., 1993, 1998) and a potentiometric titration (VINDTA) for TA (Mintrop et al., 2000). The precision is $\pm 0.05 \% / 1.1$ for DIC and $\pm 0.08 \% / 1.7 \mu \mathrm{mol} \mathrm{kg}{ }^{-1}$ for TA. The data of all obtained chemical parameters are available at the Carbon Dioxide Information Analysis Center (CDIAC; http://cdiac.ornl. gov/oceans/RepeatSections/clivar_75N.html). The physical oceanographic data (temperature, salinity and pressure) from this cruise can be found in Beszczynska-Möller and Wisotzki (2012).

\subsection{Water transport data}

An array of moorings across the deep Fram Strait from $9^{\circ} \mathrm{E}$ to $7^{\circ} \mathrm{W}$ has been maintained since 1997 by the Alfred Wegener Institute and the Norwegian Polar Institute. Since 2002, it has contained 17 moorings at $78^{\circ} 50^{\prime} \mathrm{N}$. Here we use the gridded data from the array from summer 2002 to summer 2010, as described in Beszczynska-Möller et al. (2012). The more recent data have either not been recovered yet or the processing is still in progress. The moorings contained temperature and velocity sensors at five standard depths: 75, 250, 750, 1500 and $10 \mathrm{~m}$ above the bottom. The hourly measurements were averaged to monthly values and then gridded onto a regular $5 \mathrm{~m}$ vertical by $1000 \mathrm{~m}$ horizontal grid using optimal interpolation. While the Atlantic Water in the Fram Strait has warmed since 1997, Beszczynska-Möller et al. (2012) showed that there is a strong seasonal cycle in the Atlantic Water transport through the Fram Strait, but that there is no statistically significant interannual trend between 1997 and 2010 in the volume transport. We consider the longterm average volume flux of the following water masses: Atlantic Water advected in the WSC, defined as longitude $\geq 5^{\circ} \mathrm{E}$ and depth $\leq 840 \mathrm{~m}$; Polar Water flowing southward in the EGC, defined as mean temperature $\leq 1{ }^{\circ} \mathrm{C}$ and depth $\leq 400 \mathrm{~m}$; and Recirculating and Arctic Atlantic Water which is both due to the recirculation of Atlantic Water in the Fram Strait (de Steur et al., 2014) and the long loop of Atlantic Water through the Arctic Ocean (Karcher et al., 2012), defined as longitude $\leq 1^{\circ} \mathrm{E}$ and depth $\leq 840 \mathrm{~m}$, and not as Polar Water. The estimate of the volume transport across the Fram Strait below $840 \mathrm{~m}$ from the moorings is more complicated. The method of Beszczynska-Möller et al. (2012) which was developed to study the fluxes in the WSC predicts a net southward transport of $3.2 \mathrm{~Sv}$ below $840 \mathrm{~m}$. This is unrealistic, given that there are no connections between the Nordic Seas and the Arctic Ocean below the sill depth of the Greenland-Scotland Ridge $(840 \mathrm{~m}$ ) other than the Fram Strait. No vertical displacements of isopycnals in these two basins are observed that would suggest a non-zero net transport across the Fram Strait below 840 m (von Appen et al., 2015b). The large net transport inferred by BeszczynskaMöller et al. (2012) is due to the insufficient horizontal resolution of the mooring array to explicitly resolve the westward flow of the recirculation and the mesoscale eddies. For these reasons, we assume a net flux of $0 \mathrm{~Sv}$ across the Fram Strait for the deep waters below $840 \mathrm{~m}$.

\subsection{TTD method}

A transit time distribution (TTD) model (Eq. 1) describes the propagation of a boundary condition into the interior of the ocean and is based on Green's function (Hall and Plumb, 1994).

$c\left(t_{\mathrm{s}}, r\right)=\int_{0}^{\infty} c_{0}\left(t_{\mathrm{s}}-t\right) e^{-\lambda t} \cdot G(t, r) \mathrm{d} t$

Here, $c\left(t_{\mathrm{s}}, r\right)$ is the specific tracer concentration at year $t_{\mathrm{s}}$ and location $r, c_{0}\left(t_{\mathrm{s}}-t\right)$ the boundary condition described by the tracer concentration at source year $t_{\mathrm{S}}-t$, and $G(t)$ the transit time distribution of the tracer. The exponential term corrects for the decay rate of radioactive transient tracers. Equation (2) provides a possible solution of the TTD model, based on a steady and one-dimensional advective velocity and diffusion gradient (Waugh et al., 2003).

$G(t)=\sqrt{\frac{\Gamma^{3}}{4 \pi \Delta^{2} t^{3}}} \cdot \exp \left(\frac{-\Gamma(t-\Gamma)^{2}}{4 \Delta^{2} t}\right)$

It is known as the inverse-Gaussian-transit-time distribution (IG-TTD) where $G(t)$ is defined by the width of the distribution $(\Delta)$, the mean age $(\Gamma)$ and the time range $(t)$. One can define a $\Delta / \Gamma$ ratio of the IG-TTD which represents the proportion between the advective and diffusive properties of the mixing processes as included in the TTD. The lower the $\Delta / \Gamma$ ratio, the higher is the advective share. A $\Delta / \Gamma$ ratio of 1.0 is the commonly applied ratio (unity ratio) at several tracer surveys (e.g., Waugh et al., 2004, 2006; Tanhua et al., 2008; Schneider et al., 2010, 2014; Huhn et al., 2013).

Another approach is based on a linear combination of two IG-TTDs which can be used to describe more complex ventilation patterns (Eq. 3) (Waugh et al., 2002). The variables of this model are $\Delta_{1,2}$ and $\Gamma_{1,2}$ of the two IG-TTDs and $\alpha$, which describes the ratio between both distributions. The main problem of applying this method is that five free parameters need to be determined. Hence, this model combination can be constrained with five transient tracers with sufficiently different input functions. Alternatively, predefined parameters can be used (Stöven and Tanhua, 2014).

$$
\begin{aligned}
& c\left(t_{\mathrm{s}}, r\right)=\int_{0}^{\infty} c_{0}\left(t_{\mathrm{s}}-t\right) e^{-\lambda t} . \\
& {\left[\alpha G\left(\Gamma_{1}, \Delta_{1}, t, r\right)+(1-\alpha) G\left(\Gamma_{2}, \Delta_{2}, t, r\right)\right] \mathrm{d} t}
\end{aligned}
$$


Note that the use of CFC-12 as transient tracer is limited to concentrations below the recent atmospheric level since the production of CFC-12 was phased out in the early 1990s so that the depletion rate exceeds the emission rate from the early 2000s on. This causes indistinct time information of CFC-12, since one concentration describes two dates in the atmospheric history. To this end, the use of CFC-12 is restricted to water masses with concentrations below the current atmospheric concentration limit. The emission rate of $\mathrm{SF}_{6}$ still exceeds the depletion rate so the atmospheric concentration still increases. $\mathrm{SF}_{6}$ thus provides distinct age information of water masses over the complete concentration range.

\subsection{Anthropogenic carbon and transport estimates}

The IG-TTD model can be used to estimate the total amount of anthropogenic carbon in the water column (Waugh et al., 2004). For this purpose it is assumed that the anthropogenic carbon behaves like an inert passive tracer, i.e., similar to a transient tracer. By applying Eq. (1), the concentration of anthropogenic carbon in the interior ocean $\left(\mathrm{C}_{\mathrm{ant}}\left(t_{\mathrm{s}}\right)\right)$ is given by Eq. (4).

$\mathrm{C}_{\mathrm{ant}}\left(t_{\mathrm{s}}\right)=\int_{\infty}^{0} \mathrm{C}_{\mathrm{ant}, 0}\left(t_{\mathrm{s}}-t\right) \cdot G(r, t) \mathrm{d} t$

$\mathrm{C}_{\mathrm{ant}, 0}$ is the boundary condition of anthropogenic carbon at year $t_{\mathrm{s}}-t$ and $G(r, t)$ the distribution function (see Eq. 1). The historic boundary conditions are described by the differences between the preindustrial and modern DIC concentrations at the ocean surface. These anthropogenic offsets can be calculated by applying the modern (elevated) partial pressures of $\mathrm{CO}_{2}$ and then subtracting the corresponding value of the preindustrial partial pressure. In each case, the preformed alkalinity was used as second parameter to determine the specific DIC concentrations (calculated using the Matlab version of the CO2SYS, van Heuven et al., 2011). Here we as-

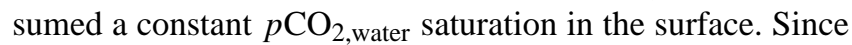
exact saturations are not well constrained, we present sensitivity calculations of different saturation states/disequilibria (see Sect. 3.6 below). The atmospheric history of $p \mathrm{CO}_{2, \mathrm{~atm}}$ is taken from Tans and Keeling (2015). The preformed alkalinity was determined by using the alkalinity-salinity relationship of MacGilchrist et al. (2014). This relationship is based on surface alkalinity and salinity measurements in the Fram Strait which were corrected for sea-ice melt and formation processes.

The time-dependent boundary conditions $\left(\mathrm{C}_{\mathrm{ant}, 0}\right)$ and Eq. (4) can then be used to calculate anthropogenic carbon concentrations $\left(\mathrm{C}_{\mathrm{ant}}\left(t_{\mathrm{s}}\right)\right)$ and the corresponding mean age. Finally, the mean age of Eq. (4) can be set in relation to the transient tracer-based mean age of the water and allows for back-calculating $\mathrm{C}_{\mathrm{ant}}\left(t_{\mathrm{s}}\right)$, i.e., it provides the link between the tracer concentration and the anthropogenic carbon concentration.

We then proceed to estimate transports of anthropogenic carbon through the Fram Strait. Transports are the product of concentrations multiplied by velocities integrated over an area. We assume that the trace gas concentrations change relatively slowly between years and that there are no significant seasonal changes. Hence, we can take the concentrations from summer 2012 to be informative about other seasons and years within some range from 2012. On the other hand, it is known that velocities change strongly between seasons (and on shorter time scales), but on average not significantly between years in the Fram Strait (BeszczynskaMöller et al., 2012). It follows that the measured (20022010) long-term average volume transport is representative of the volume transport through the Fram Strait in the late 2000s-early 2010s. Likewise, the measured $\mathrm{C}_{\mathrm{ant}}$ concentrations in summer 2012 are representative of the $\mathrm{C}_{\text {ant }}$ concentrations in the late 2000s-early 2010s. The product of the two is then our estimate of the $\mathrm{C}_{\mathrm{ant}}$ transport through the Fram Strait in the late 2000s-early 2010s.

\section{Results and Discussion}

\subsection{Water masses in the Fram Strait}

To highlight the different transient tracer characteristics, we defined the water mass type of each sample by using the water mass properties suggested by Rudels et al. $(2000,2005)$ and the salinity and temperature data of this cruise from Beszczynska-Möller and Wisotzki (2012).

Water masses of the Arctic Ocean are the Polar Surface Water (PSW), which is the cold and low saline surface and halocline water; the warm Polar Surface Water, defined by a potential temperature $(\Theta)>0$, which comprises sea ice melt water due to interaction with warm Atlantic Water and due to solar radiation; the Arctic Atlantic Water which derives from sinking Atlantic Water due to cooling in the Arctic Ocean. The deep water masses are upper Polar Deep Water (uPDW), Canadian Basin Deep Water (CBDW) and Eurasian Basin Deep Water (EBDW). Deep water formation, e.g., on the Arctic shelves, usually involves densification due to brine rejection. The Eurasian Basin Deep Water mixes with Greenland Sea Deep Water so that this layer corresponds to two sources in the Fram Strait (von Appen et al., 2015b).

Water masses of the Atlantic Ocean/Nordic Seas are the warm and saline Atlantic Water (AW) and the corresponding Recirculating Atlantic Water (RAW); the Arctic Intermediate Water (AIW) which is mainly formed in the Greenland Sea; the Nordic Seas Deep Water (NDW) which comprises Greenland Sea Deep Water (GSDW), Iceland Sea Deep Water (ISDW) and Norwegian Sea Deep Water (NSDW) and is formed by deep convection during winter time. 


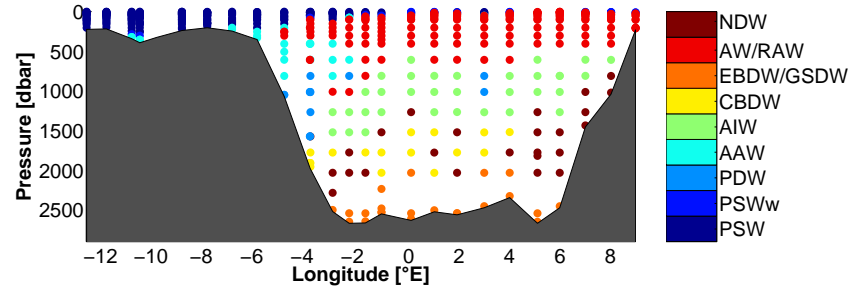

Figure 2. Water masses in the Fram Strait: Nordic Seas Deep Water (NDW), Atlantic Water/Recirculating Atlantic Water (AW/RAW), Eurasian Basin Deep Water (EBDW)/Greenland Sea Deep Water (GSDW), Canadian Basin Deep Water (CBDW), Arctic Intermediate Water (AIW), Arctic Atlantic Water (AAW), Upper Polar Deep Water (uPDW), Polar Surface Water warm (PSWw) and Polar Surface Water (PSW).

Figure 2 shows the zonal water mass distribution in the Fram Strait based on salinity and temperature data from the CTD. The surface layer is dominated by Atlantic Water and Recirculating Atlantic Water in the east and by Polar Surface Water in the west with a transition between $6^{\circ} \mathrm{W}$ and $4^{\circ} \mathrm{E}$ where Polar Surface Water overlays the Atlantic Water. Warm Polar Surface Water can be found within the Atlantic Water between 4 and $8^{\circ} \mathrm{E}$. The Atlantic Water layer extends down to $\sim 600 \mathrm{~m}$. Arctic Atlantic Water can be found at the upper continental slope of Greenland between 300 and $700 \mathrm{~m}$. The intermediate layer between 500 and $1600 \mathrm{~m}$ consists mainly of Arctic Intermediate Water and, at the Greenland slope, partly of Upper Polar Deep Water. Canadian Basin Deep Water can be found between 1600 and $2400 \mathrm{~m}$ west of $4^{\circ} \mathrm{E}$. Nordic Seas Deep Water is the prevailing water mass along the continental slope of Svalbard between 700 and $2400 \mathrm{~m}$ but can be also observed in the range of the Canadian Basin Deep Water layer. The Eurasian Basin Deep Water/Greenland Sea Deep Water forms the bottom layer below $2400 \mathrm{~m}$.

\subsection{Transient tracer and DIC distributions}

Figure 3 shows the partial pressure of $\mathrm{CFC}-12$ and $\mathrm{SF}_{6}$ at the zonal section across the Fram Strait. Both tracers have significant concentrations through the entire water column and show a similar distribution pattern. The Atlantic Water shows a relatively homogeneous distribution of both tracers, with CFC-12 partial pressures $>450 \mathrm{ppt}$ and $\mathrm{SF}_{6}>6 \mathrm{ppt}$. The Polar Surface Water at the shelf region shows a more distinct structure with partial pressures between 4 and 8 of $\mathrm{SF}_{6}$ and $410-560 \mathrm{ppt}$ of CFC-12. The smaller concentration gradient of CFC-12 in the surface compared to $\mathrm{SF}_{6}$ is related to the recently decreasing atmospheric concentration of CFC-12, which causes only slightly varying boundary conditions at the air-sea interface (see Sect. 2.3). The high-tracerconcentration layer of the Polar Surface Water extends further eastward as overlaying tongue of the Atlantic Water between 2 and $6^{\circ} \mathrm{W}$. The intermediate layer between 500 and

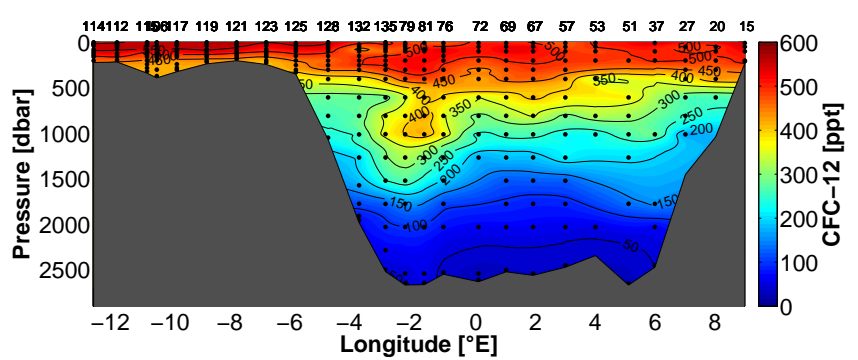

(a)

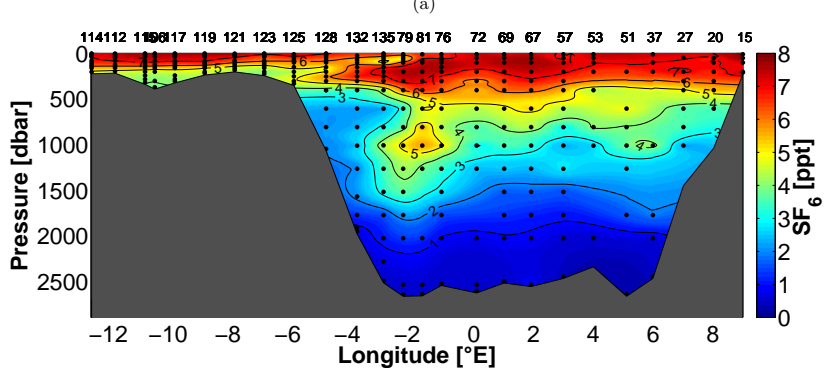

(b)

Figure 3. Distribution of the partial pressure of (a) CFC-12 and (b) $\mathrm{SF}_{6}$ along the zonal section in the Fram Strait.

$1600 \mathrm{~m}$ is characterized by a clear tracer minimum along the continental slope of Greenland with partial pressures between 1.8 and 4.0 of $\mathrm{SF}_{6}$ and $150-350$ ppt of CFC-12 and mainly comprises Arctic Atlantic Water. East of this minimum, a remarkable tracer maximum can be observed at 1$3^{\circ} \mathrm{W}$ with partial pressures between 3 and 6 of $\mathrm{SF}_{6}$ and 250 $450 \mathrm{ppt}$ of CFC-12. A smaller maximum can be observed between 5 and $6^{\circ} \mathrm{E}$ at $\sim 1000 \mathrm{~m}$ with partial pressures of $\sim 5$ of $\mathrm{SF}_{6}$ and $\sim 330 \mathrm{ppt}$ of CFC-12. Both tracer maxima likely correspond to recently ventilated water which mainly affected the Arctic Intermediate Water and partly the Atlantic Water in the transition zone of both water masses. The Arctic Intermediate Water in the Fram Strait thus consists of recently ventilated areas and less ventilated areas, which is also indicated by the large range of transient tracer concentrations. The remaining intermediate layer above $1700 \mathrm{~m}$ is characterized by lower partial pressures between 2 and 3 of $\mathrm{SF}_{6}$ and $150-300 \mathrm{ppt}$ of CFC-12 with concentrations decreasing with depth. This gradient extends throughout the deep water layers down to the bottom with partial pressures from 2 down to $0.2 \mathrm{ppt}$ of $\mathrm{SF}_{6}$ and from 150 down to $34 \mathrm{ppt}$ of CFC-12.

Figure 4 shows the DIC concentrations along the zonal section. The Greenland shelf region shows concentrations between 1970 in the surface and $2145 \mu \mathrm{mol} \mathrm{kg}{ }^{-1}$ at $\sim 200 \mathrm{~m}$. The upper $200 \mathrm{~m}$ between 4 and $8^{\circ} \mathrm{E}$ shows increasing concentrations with depth between 2070 and $2155 \mu \mathrm{mol} \mathrm{kg}{ }^{-1}$. There are three significant DIC maxima below $200 \mathrm{~m}$. Two are located at the continental slope of Svalbard at 300 800 and at $1400-2100 \mathrm{~m}$, with concentrations $>2158$ and a maximum concentration of $2167 \mu \mathrm{mol} \mathrm{kg}{ }^{-1}$. The third max- 


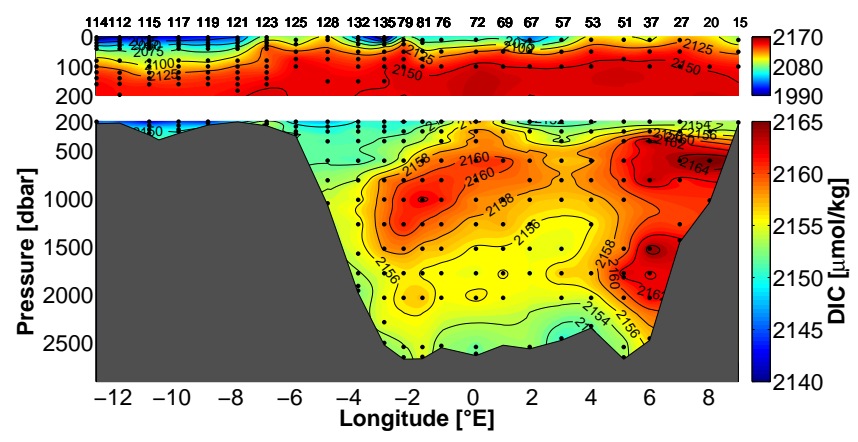

Figure 4. Distribution of dissolved inorganic carbon (DIC, in $\mu \mathrm{mol} \mathrm{kg}{ }^{-1}$ ) along the zonal section in the Fram Strait.

imum corresponds to the transient tracer maximum at 1$3^{\circ} \mathrm{W}$ but extends further eastward, with concentrations between 2158 and $2162 \mu \mathrm{mol} \mathrm{kg}{ }^{-1}$. The area of the EGC at 3$8^{\circ} \mathrm{W}$ is characterized by concentrations between 2118 and $2152 \mu \mathrm{mol} \mathrm{kg} \mathrm{k}^{-1}$. The deep water below $1700 \mathrm{~m}$ shows concentrations between 2150 and $2158 \mu \mathrm{mol} \mathrm{kg}^{-1}$.

\subsection{Transient tracers and the IG-TTD}

The IG-TTD can be numerically constrained using transient tracer couples, $\mathrm{CFC}-12$ and $\mathrm{SF}_{6}$ in our case, which provide information about the mean age and the parameters of the IG-TTD (Waugh et al., 2002; Sonnerup et al., 2013; Stöven and Tanhua, 2014). The method of validity areas, introduced in Stöven et al. (2015), is used to determine the applicability of the tracer couple. For this purpose, the tracer age is calculated from the transient tracer concentrations (Waugh et al., 2003) which provide the tracer age relationship of the tracer couple. Figure 5 shows the tracer age relationship of our field data (colored by water mass) in relation to the range of theoretical tracer age relationships of the IG-TTD, i.e., for $\Delta / \Gamma$ ratios between 0.1 and 1.8 , which describe the range from advectively dominated to diffusively dominated water masses (grey shaded area). The black line in Fig. 5 denotes the tracer age relationship based on the unity ratio of $\Delta / \Gamma=1.0$. Field data which correspond to this unity ratio would be centered around the black line.

The Fram Strait data can generally be separated into two sets of tracer age relationships. The upper set consists of water masses of Atlantic origin and deep waters, namely Atlantic Water/Recirculating Atlantic Water, Arctic Intermediate Water, Nordic Seas Deep Water, Eurasian Basin Deep Water/Greenland Sea Deep Water and Canadian Basin Deep Water whereas the lower set only consists of water masses of polar origin, namely Polar Surface Water, warm Polar Surface Water, Arctic Atlantic Water and upper Polar Deep Water. Note that the Arctic Atlantic Water and upper Polar Deep Water merge with the upper set for $\mathrm{SF}_{6}$ tracer age larger than about 25 years. However, the upper set does not correspond to the unity ratio and, moreover, it is outside the validity area

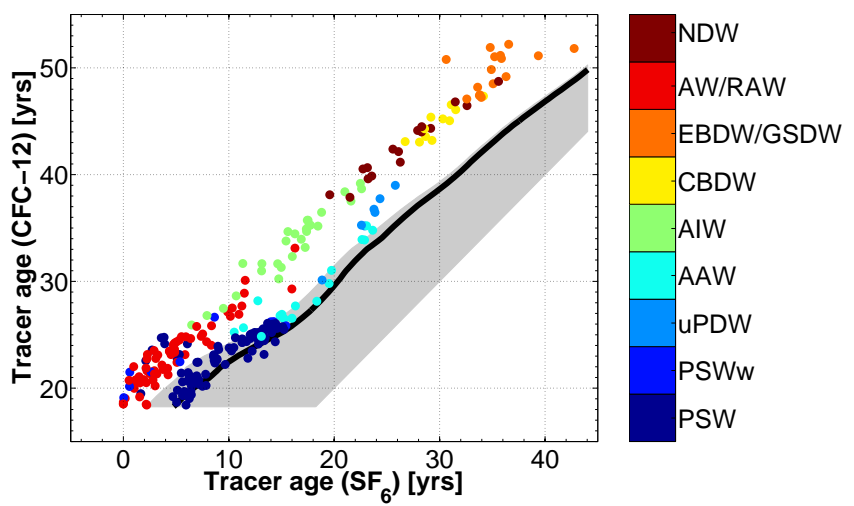

Figure 5. Validity area of the IG-TTD, defined by the tracer couple CFC-12 and $\mathrm{SF}_{6}$ (grey shaded area). The black line indicates the IGTTD-based tracer age relationship using the unity ratio of $\Delta / \Gamma=$ 1.0. The field data are colored by the type of water mass. The lower set (blue dots) describes surface and intermediate water of Arctic origin whereas the upper set includes water of Atlantic origin and deep water masses.

of the IG-TTD. Water masses related to the lower set can be applied to the IG-TTD with tendencies toward higher $\Delta / \Gamma$ ratios $(>1.0)$ since the data are clearly above the black line, indicating a dominance of diffusive processes.

Another approach is provided by the linear combination of two IG-TTDs. Since we only have the data of two transient tracers, we used the same predefined parameters as described in Stöven and Tanhua (2014) which include one more diffusive water parcel $\left(\Delta_{1} / \Gamma_{1}=1.4\right)$ and one very advective water parcel $\left(\Delta_{2} / \Gamma_{2}=0.6\right)$. Similar to Figure 5,Fig. 6 shows the validity area of the linear combination of two IG-TTDs for different $\alpha$ of $0.2,0.5$ and 0.8 . Although this combination describes several scenarios from highly advective to diffusive mixing of two distributions, it can be seen that most of the observed data points are still outside the validity area. Thus, the tracer age relationship between $\mathrm{CFC}-12$ and $\mathrm{SF}_{6}$ can be described neither by the IG-TTD nor a linear combination of two IG-TTDs.

Based on the raw field data and assumptions implemented in the IG-TTD (such as constant mixing processes along the flow pathway as well as constant saturation of the gases at the surface before entering deeper layers), the IG-TTD or linear combinations of the IG-TTD can only partly describe the ventilation pattern of water masses in the Fram Strait. Nevertheless, by comparing the shape of the two field data sets with the shape of the black line in Fig. 5, both sets show similar characteristics, such as the unity ratio or, generally, IG-TTD-based tracer age relationships. This opens up the possibility to use the IG-TTD the other way around, i.e., to assume a fixed $\Delta / \Gamma$ ratio to determine the deviation of transient tracer concentrations rather than using the transient tracer concentration to determine the $\Delta / \Gamma$ ratio. Since several publications found the unity ratio of $\Delta / \Gamma=1.0$ to be 

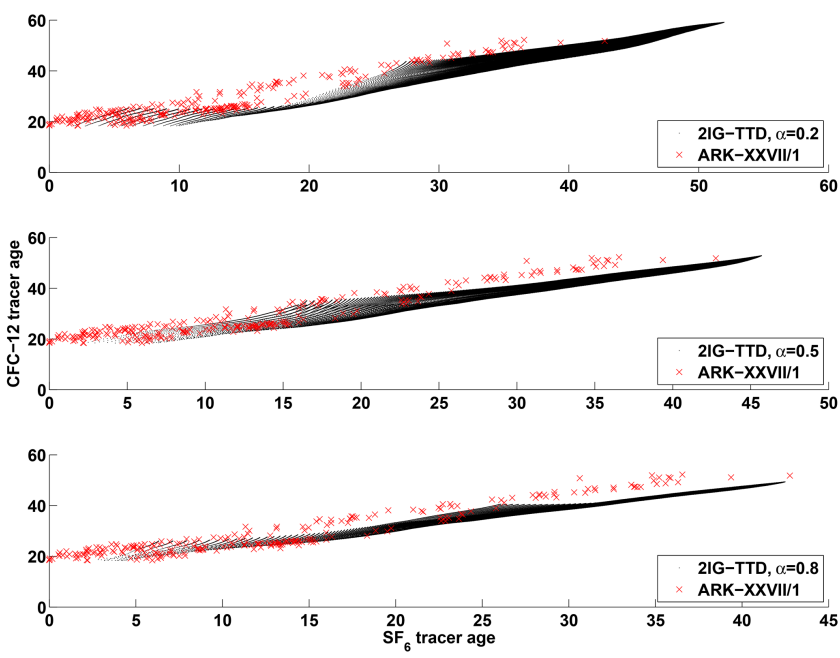

Figure 6. Validity areas of linear combinations of two IG-TTDs for $\alpha=0.2,0.5,0.8, \Delta_{1} / \Gamma_{1}=1.4, \Delta_{2} / \Gamma_{2}=0.6$ and $\Gamma_{1,2}=1-500$ (black dots). The field data are described by the red crosses. The lower the $\alpha$ value, the higher the share of the diffusively dominated IG-TTD.

valid in large parts of the ocean, we assumed that this is also true for water masses in the Fram Strait. Figure 7 shows the mean tracer age relationship of the upper set (red line) and the tracer age relationship of the unity ratio (black line/same as in Fig. 5). The offset of the field data related to the unity ratio suggests an undersaturation of CFC-12 and/or a supersaturation of $\mathrm{SF}_{6}$ (see black box in Fig. 7). This uncommon coexistence of under- and supersaturated transient tracers is discussed in the following section.

\subsection{Saturations and excess $\mathrm{SF}_{6}$}

The surface saturations of transient tracers are influenced by sea surface temperature and salinity, ice coverage, wind speed, bubble effects, atmospheric growth rate of the tracer and the boundary dwell time of the water parcel (i.e., the time the water parcel is in contact with the atmosphere). However, the saturation state of transient tracers at the air-sea interface before, during and after water mass formation is rarely known, since water mass formation generally occurs in winter at high latitudes, which renders it almost impossible to obtain measurements. Shao et al. (2013) provide modeled data of monthly surface saturations of CFC-11, CFC-12 and $\mathrm{SF}_{6}$ from 1936 to 2010 on a global scale. This model output can be used to estimate the tracer saturation ratio of different water masses by using the surface saturation of the specific formation area and yearly formation period. The formation types and areas are notably different for water masses that occur in the Fram Strait. The model output shows high variabilities in surface saturations at different formation sites, namely the Greenland Sea, the Arctic shelf regions and the Arctic open water (Fig. 8). In contrast, the tracer age rela-

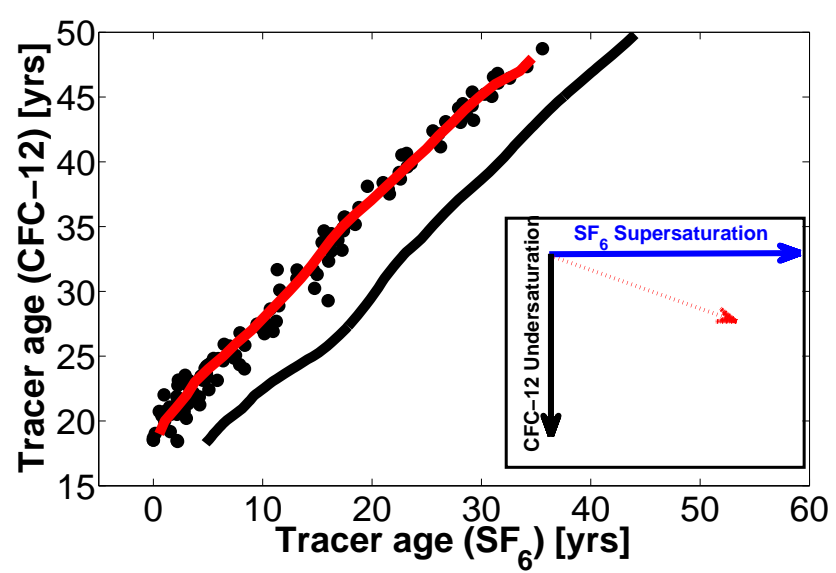

Figure 7. Relation between the IG-TTD-based tracer age relationship of the unity ratio (black line) and the mean tracer age relationship of the upper set of the field data (red line). The shape of both curves indicates similarities between the modeled and field data. The difference can be explained by undersaturation of CFC-12 and/or supersaturation of $\mathrm{SF}_{6}$ (see inset).

tionships of the two sets in Fig. 5 indicate relatively similar deviations in saturation. The complex boundary conditions in the Arctic, e.g., possible gas exchange through ice cover and the changing extent of the ice cover, might bias the results of the saturation model. Therefore, we only used the surface saturation of the Greenland Sea (Area 1 in Fig. 8) which agrees with the findings of Tanhua et al. (2008) who used available field data to investigate historic tracer saturations. The IG-TTD-based mean age provides the link between the observed tracer concentrations and the corresponding time-dependent saturation. Therefore, the saturation corrections were applied to the atmospheric history (boundary conditions) of each tracer. These new boundary conditions are then applied to the measured tracer concentrations and the IG-TTD which then yields a saturation-corrected mean age. This mean age in turn can then be used to back-calculate the saturation-corrected tracer concentrations using the original (uncorrected) boundary conditions.

The $\mathrm{SF}_{6}$ excess is estimated using the corrected CFC12 concentrations and the IG-TTD $(\Delta / \Gamma=1.0)$ to calculate theoretical $\mathrm{SF}_{6}$ concentrations of the water parcel, i.e., back-calculated $\mathrm{SF}_{6}$ concentrations. The difference between the theoretical $\mathrm{SF}_{6}$ concentration and the measured $\mathrm{SF}_{6}$ concentration denotes the $\mathrm{SF}_{6}$ excess in the water. Note that this $\mathrm{SF}_{6}$ excess is based on the assumption that the IGTTD and unity ratio describe the prevailing ventilation pattern of the water masses. Figure 9 shows the $\mathrm{SF}_{6}$ excess in $\mathrm{fmol} \mathrm{kg} \mathrm{k}^{-1}$ and ppt for depths below $200 \mathrm{~m}$. This upper depth limit is invoked by the fact that CFC- 12 concentrations above the current atmospheric concentration limit cannot be applied to the IG-TTD. The $\mathrm{SF}_{6}$ excess is much higher $\left(0.5-0.8 \mathrm{fmol} \mathrm{kg}^{-1} / 1.0-1.6 \mathrm{ppt}\right)$ for northward-propagating water masses compared to water masses of Arctic origin $(0-$ 

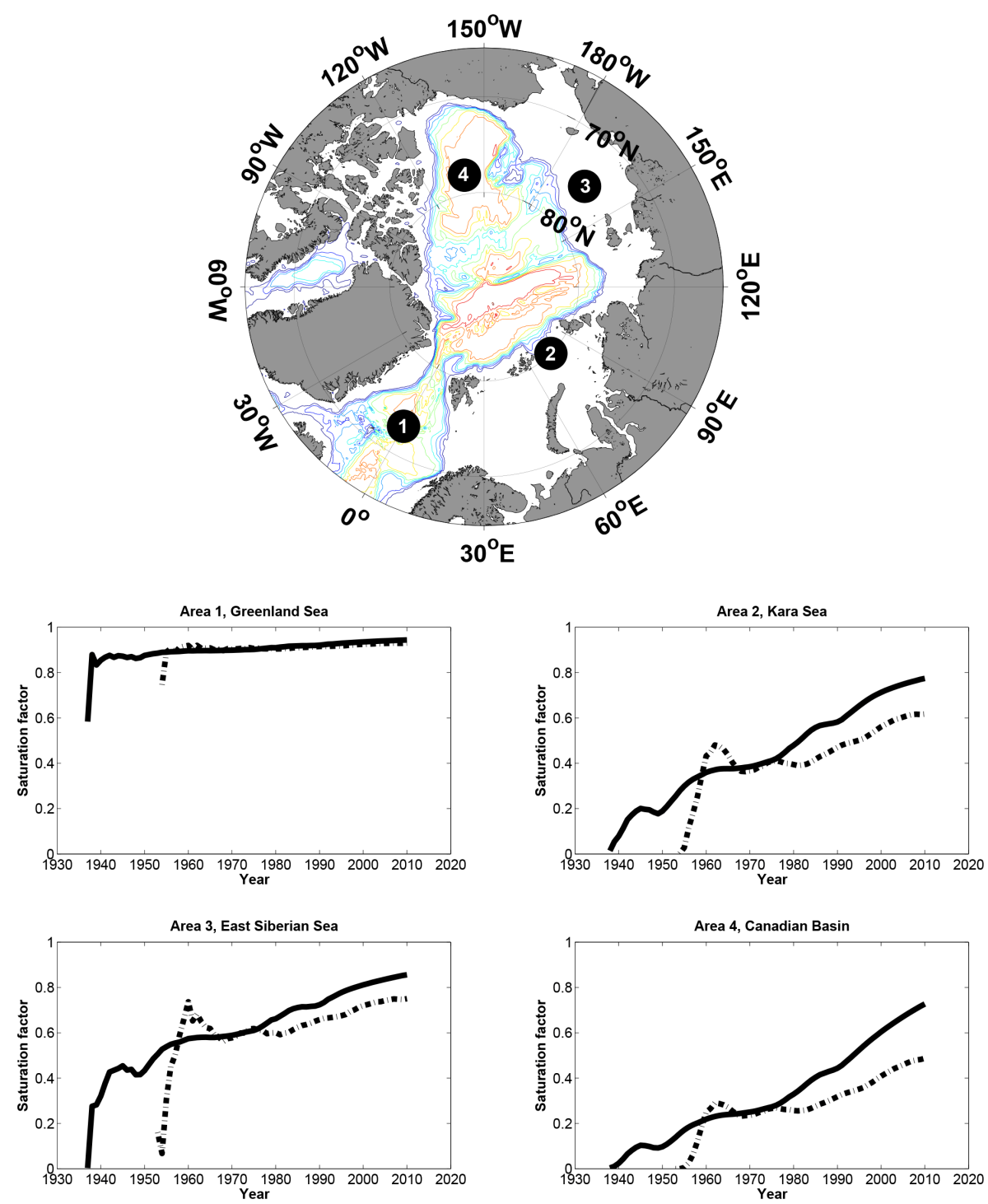

Figure 8. Surface saturations of CFC-12 (black solid line) and $\mathrm{SF}_{6}$ (black dash-dotted line) based on the model output of Shao et al. (2013). The model output shows mean values of the corresponding grids with a dimension of $300 \times 300 \mathrm{~nm}$ for typical source regions of the following different water mass types: (1) the Greenland Sea, (2-3) Arctic shelf regions and (4) Arctic open water/fast-ice region.

$\left.0.4 \mathrm{fmol} \mathrm{kg}^{-1} / 0-0.8 \mathrm{ppt}\right)$. There are at least two possible effects which can cause such significant supersaturations of $\mathrm{SF}_{6}$.

One possibility refers to the deliberate tracer release experiment in 1996 where $320 \mathrm{~kg}(\sim 2190 \mathrm{~mol})$ of $\mathrm{SF}_{6}$ were introduced into the central Greenland Sea (Watson et al., 1999). The patch was redistributed by mixing processes and entered the Arctic Ocean via the Fram Strait and Barents Sea Opening and the North Atlantic via Denmark Strait and the Faroe Bank Channel (Olsson et al., 2005; Tanhua et al., 2005; Marnela et al., 2007). Assuming that 50-80\% of the deliberately released $\mathrm{SF}_{6}$ still remains in the Nordic Seas and the Arctic Ocean $(1095-1752 \mathrm{~mol})$ and that $10--50 \%$ of the corresponding total water volume of $1.875 \times 10^{18}-9.375 \times 10^{18} \mathrm{~L}$
(Eakins and Sharman, 2010) is affected, a mean offset of $0.12-0.93 \mathrm{fmol} \mathrm{L}^{-1}$ might be found. This mean offset is in the range of the observed $\mathrm{SF}_{6}$ excess concentrations. However, CFC-12 and $\mathrm{SF}_{6}$ data of the Southern Ocean (Stöven et al., 2015) show similar tracer age relationships compared to the Fram Strait data but with no influence of deliberately released $\mathrm{SF}_{6}$. This indicates that another source of excess $\mathrm{SF}_{6}$ may exist which is much larger than the source of the tracer release experiment.

Liang et al. (2013) introduced a model which estimates supersaturations of dissolved gases by bubble effects in the ocean. This model predicted an increasing supersaturation for increasing wind speed and decreasing temperature, i.e., the bubble effect becomes more significant at high latitudes. 


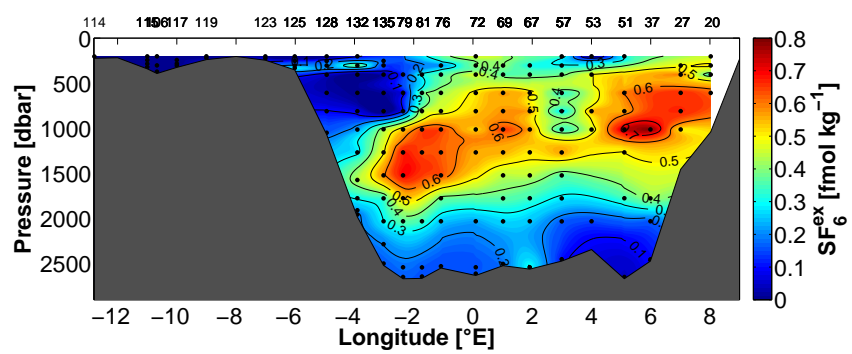

(a)

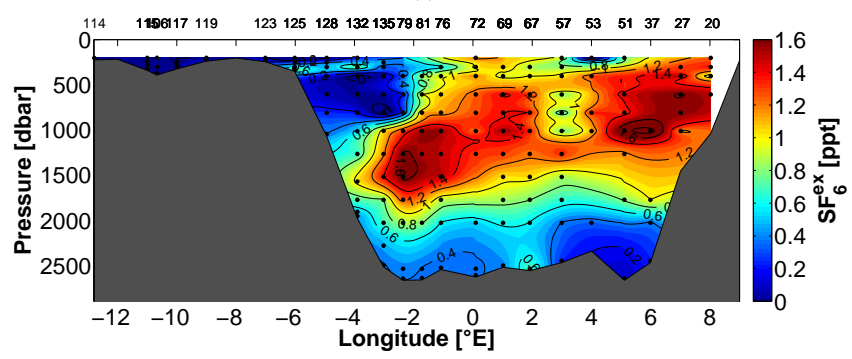

(b)

Figure 9. Distribution of $\mathrm{SF}_{6}$ excess (a) concentrations in fmol kg $\mathrm{kg}^{-1}$ and (b) partial pressures in ppt. The upper $200 \mathrm{~m}$ and station 15 cannot be calculated due to the atmospheric concentration limit of CFC-12 which inhibits an application of the IG-TTD.

Furthermore, Liang et al. (2013) show that the magnitude of supersaturation depends on the solubility of the gas. The less soluble a gas, the more supersaturation can be expected. Supporting this, Stöven et al. (2015) describe surface measurements of $\mathrm{SF}_{6}$ and CFC-12 directly after heavy wind conditions in the Southern Ocean where $\mathrm{SF}_{6}$ supersaturations of $20-50 \%$ could be observed. The CFC- 12 concentrations were only affected to a minor extent which can be explained by the differences in solubility. This bubble-induced supersaturation can also be expected to occur during the process of water mass formation in the Greenland Sea, which usually occurs during late winter, i.e., during a period with low surface temperatures and heavy wind conditions. Furthermore, the maximum $\mathrm{SF}_{6}$ excess in the Arctic Intermediate Water layer in Fig. 9 and the generally elevated tracer concentrations of CFC-12 and $\mathrm{SF}_{6}$ in the same area (see Fig. 3) reaffirm the assumption of bubble-induced supersaturation of $\mathrm{SF}_{6}$. However, this hypothesis stands in opposition to the current assumption that trace gases are generally undersaturated during water mass formation (Tanhua et al., 2008; Shao et al., 2013).

Future investigations are necessary to determine the different impact of under- and supersaturation effects on soluble gases at the air-sea interface. It can be expected that possible scenarios are not restricted to distinct saturation states any longer but rather comprise mixtures of equilibrated, underand supersaturated states of the different gases.
Table 1. Mean ( \pm standard deviation) concentrations of anthropogenic carbon $\left(\mathrm{C}_{\mathrm{ant}}\right)$ and mean age in the Fram Strait, separated in water mass types.

\begin{tabular}{lrr}
\hline Water mass & $\begin{array}{r}\mathrm{C}_{\text {ant }} \\
\left(\mu \mathrm{mol} \mathrm{kg}{ }^{-1}\right)\end{array}$ & $\begin{array}{r}\text { Mean age } \\
\text { (years) }\end{array}$ \\
\hline AW/RAW & $50( \pm 6)$ & $9( \pm 10)$ \\
PSWw & $46( \pm 5)$ & $9( \pm 10)$ \\
PSW & $43( \pm 2)$ & $7( \pm 6)$ \\
AAW & $38( \pm 5)$ & $32( \pm 15)$ \\
AIW & $31( \pm 5)$ & $54( \pm 20)$ \\
uPDW & $28( \pm 4)$ & $69( \pm 19)$ \\
NDW & $18( \pm 4)$ & $143( \pm 44)$ \\
CBDW & $15( \pm 2)$ & $173( \pm 23)$ \\
EBDW/GSDW & $11( \pm 1)$ & $254( \pm 32)$ \\
\hline
\end{tabular}

\subsection{Anthropogenic carbon and mean age}

Since CFC-12 is not affected by tracer release experiments, and possibly only to a minor extent by bubble effects, we used this tracer to calculate the mean age of the water and the corresponding anthropogenic carbon content. $\mathrm{SF}_{6}$ was only used in the surface and upper halocline, i.e., where CFC12 exceeds the atmospheric concentration limit of $528 \mathrm{ppt}$ and where effects of $\mathrm{SF}_{6}$ supersaturation are comparatively small. Saturation-corrected tracer data were applied for subsurface data below $200 \mathrm{~m}$ whereas surface data were found to be near equilibrium state with the atmosphere. Figure 10 shows the anthropogenic carbon distribution and Fig. 11 shows the mean age of the water masses. As expected from the relation between transient tracers, mean age and anthropogenic carbon, the distribution patterns are similar to that of transient tracers. The highest anthropogenic carbon concentrations of $50-55 \mu \mathrm{mol} \mathrm{kg}-1$ were found in the upper $600 \mathrm{~m}$ of the Atlantic Water/Recirculating Atlantic Water and slightly lower concentrations of $40-45 \mu \mathrm{mol} \mathrm{kg}{ }^{-1}$ in the Polar Surface Water/warm Polar Surface Water layer. The mean age of these water masses is $0-20$ years. Note that these water layers show the highest mean current velocities in the Fram Strait (Beszczynska-Möller et al., 2012). The area of the tracer maximum at $1-3^{\circ} \mathrm{W}$ shows elevated concentrations of $35-40 \mu \mathrm{mol} \mathrm{kg}^{-1}$ and a mean age of $20-40$ years. The remaining water layers below $600 \mathrm{~m}$ show anthropogenic carbon concentrations lower than $35 \mu \mathrm{mol} \mathrm{kg}{ }^{-1}$ with decreasing concentrations with increasing depth; anthropogenic carbon is comparatively low $\left(<10 \mu \mathrm{mol} \mathrm{kg}{ }^{-1}\right)$ in deep water masses such as Canadian Basin Deep Water and Eurasian Basin Deep Water/Greenland Sea Deep Water. Accordingly, the mean age increases with increasing depth from 30 years to 280 years and shows a maximum mean age of 286 years in the bottom layer at the prime meridian. Table 1 shows the mean values and standard deviation of each specific water layer. 


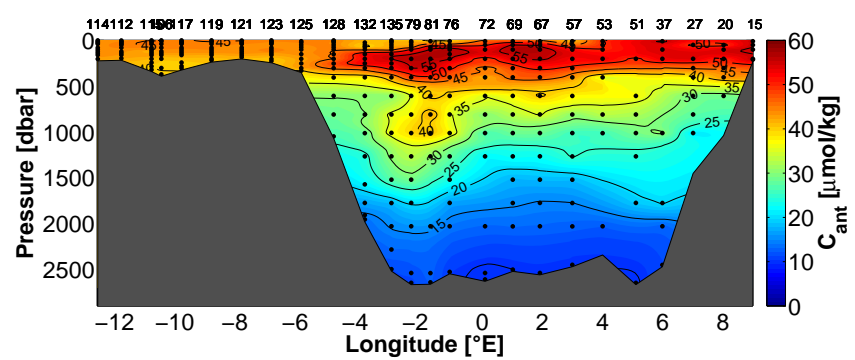

Figure 10. Distribution of anthropogenic carbon in $\mu \mathrm{mol} \mathrm{kg}-1$ along the zonal section in the Fram Strait.

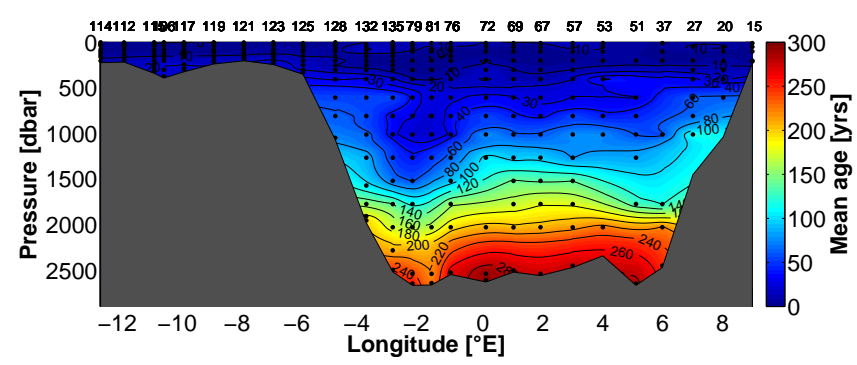

Figure 11. Distribution of the mean age based on saturationcorrected CFC-12 data below $200 \mathrm{~m}$ and unaltered $\mathrm{SF}_{6}$ data in shallower depths.

The determined values are comparable to the findings of Jutterström and Jeansson (2008), who used a similar method to determine anthropogenic carbon of the EGC in 2002. The Fram Strait section of their data set shows a similar distribution pattern of anthropogenic carbon but with lower concentration levels compared to our data from 2012. The concentration differences between the 2002 and 2012 data indicate an increase in the anthropogenic carbon content between 25 and $35 \%$ in the entire water column during the elapsed 10 years. This corresponds to an increase of 2 in the Atlantic Water, an increase of 1 in the Polar Water and an increase between 0.5 and $1 \mu \mathrm{mol} \mathrm{kg}{ }^{-1} \mathrm{yr}^{-1}$ in the deeper water layers. Based on these current rates of increase, it can be assumed that the import of anthropogenic carbon by Atlantic Water becomes more dominant compared to the export by Polar Water in the future. Furthermore, when looking at the different gateways to the Arctic Ocean, it can be assumed that the Atlantic Water entering the Arctic Ocean via the Barents Sea has similar anthropogenic carbon concentrations as the Fram Strait and that the outflow water through the Canadian Archipelago has similar concentrations as the Polar Water in the Fram Strait. The inflow of Pacific Water transports $\sim 46 \mu \mathrm{mol} \mathrm{kg}{ }^{-1}$ of anthropogenic carbon into the Arctic Ocean (Stöven, unpublished data 2014). This implies that the inflowing water masses transport more anthropogenic carbon into the Arctic Ocean than the outflowing water masses since the water mass exchange must be balanced.

\subsection{Sensitivities in anthropogenic carbon}

The calculations presented above are based on the ideal case of $p \mathrm{CO}_{2, \mathrm{~atm}}=p \mathrm{CO}_{2 \text {,water }}$ at the sea surface before entering the ocean interior, and the assumption that the saturation correction of the tracers and the unity ratio of the IGTTD are true for water masses in the Fram Strait. Since these three parameters cannot be directly determined, it is very likely that deviations from the ideal case can occur. Therefore, we present the corresponding sensitivities in the following text. The sensitivities are determined by changing only one parameter and keeping the others constant at ideal conditions. Figure 12a and $b$ show the sensitivities of changes in tracer saturation using the example of CFC-12 since most of the anthropogenic carbon calculations are based on this tracer. Small deviations of $\pm 5 \%$ in CFC-12 saturations cause only small deviations of anthropogenic carbon concentrations of $\pm 1 \mu \mathrm{mol} \mathrm{kg}-1 / \pm 2-4 \%$. Furthermore, the sensitivity depends on the partial pressure range of CFC-12. The lower the partial pressure, the less sensitive the anthropogenic carbon concentrations are to changes in CFC-12 saturation. The maximum deviations are $\pm 6 \mu \mathrm{mol} \mathrm{kg}-1 / \pm 11-16 \%$ for partial pressure $>400$ ppt. The white patches in Fig. 12a and b correspond to supersaturations which exceed the atmospheric concentration limit of CFC-12.

Figure $12 \mathrm{c}$ and $\mathrm{d}$ show the sensitivities due to changes in the $\Delta / \Gamma$-ratio of the IG-TTD. The sensitivity is very low $(<1 \mu \mathrm{mol} \mathrm{kg}-1 /<5 \%)$ for most of the ratio and concentration range. Partial pressures below $100 \mathrm{ppt}$ and $\Delta / \Gamma<$ 0.4 show the highest sensitivity with deviations between 5 and $10 \mu \mathrm{mol} \mathrm{kg} \mathrm{kg}^{-1} / 50-200 \%$. The unusual sensitivity distribution is related to the indistinct boundary condition of CFC-12 in recent years and the distribution function of the TTD. For more detailed information, see Stöven et al. (2015). The sensitivities of deviations in $p \mathrm{CO}_{2}$ saturations are shown in Fig. 12e and f. The absolute error is characterized by a relatively steady change with changing saturation states. The absolute error is more or less independent of the partial pressure of CFC-12 and leads to maximum deviations of $\pm 20-25 \mu \mathrm{mol} \mathrm{kg}{ }^{-1}$. The relative error (0-200\%) shows an increasing sensitivity of anthropogenic carbon concentrations to changes in $p \mathrm{CO}_{2}$ saturations and decreasing CFC-12 partial pressures. Note that a negative deviation of $100 \%$ corresponds to anthropogenic carbon concentration of $0 \mu \mathrm{mol} \mathrm{kg}{ }^{-1}$ which is also indicated by the turning points where the contour lines continue parallel to the $x$ axis in Fig. 12e. This indicates that small uncertainties in $p \mathrm{CO}_{2}$ saturations can cause large errors in anthropogenic carbon estimates for low tracer concentrations, i.e., for a high mean age of the water. Furthermore, it is unclear to what extent the time period and type of sea ice coverage, as well as the sea ice formation and melting processes, bias the $p \mathrm{CO}_{2}$ and tracer saturations at high latitudes. The uncertainty of the $p \mathrm{CO}_{2}$ saturation remains the largest error source although the saturation of $p \mathrm{CO}_{2}$ and $\mathrm{CFC}-12$ counteract each other. 


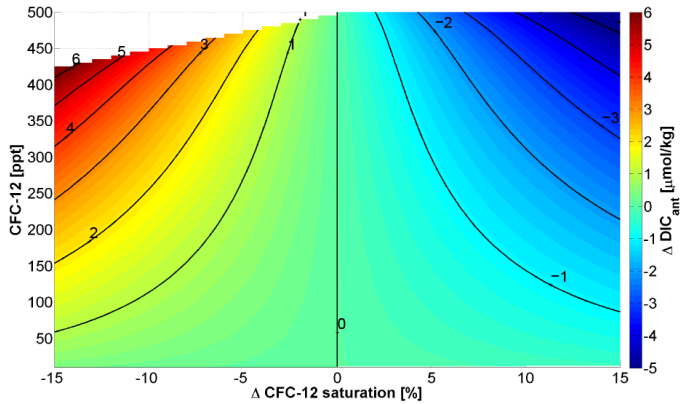

(a)

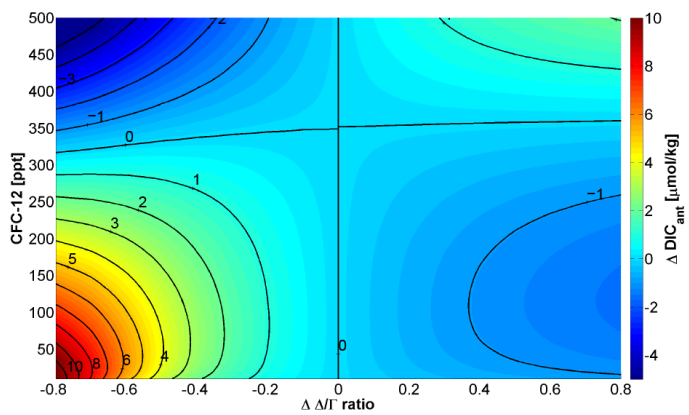

(c)

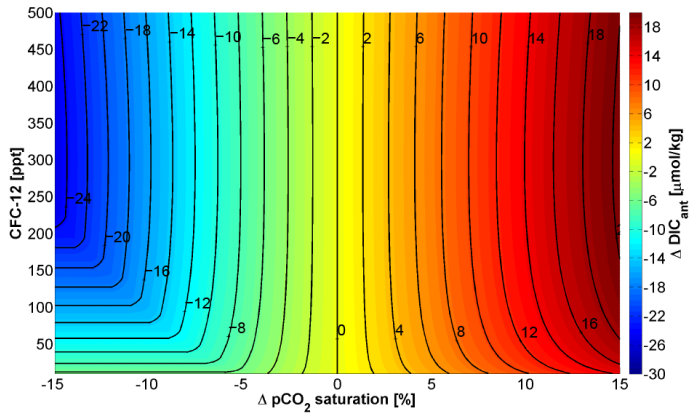

(e)

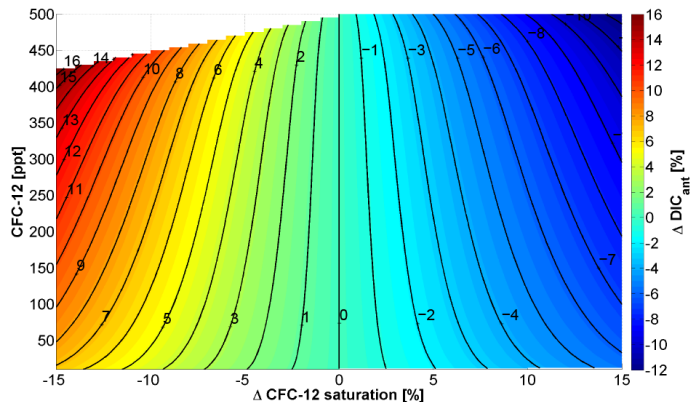

(b)

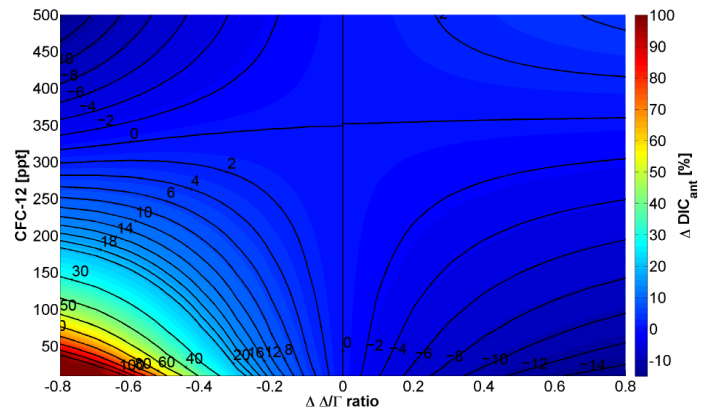

(d)

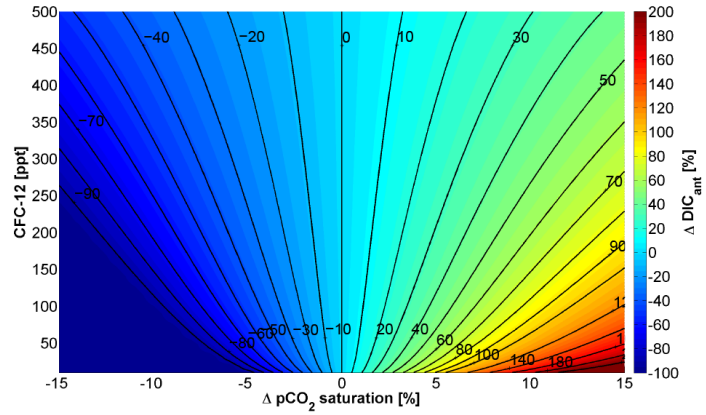

(f)

Figure 12. Anthropogenic carbon concentration sensitivities as a function of CFC-12 concentrations vs. changes in (a, b) CFC-12 saturation, (c, d) $\Delta /$ rratio and (e, f) $p \mathrm{CO}_{2}$ saturation. Deviations are stated in absolute (left panels) and relative (right panels) values. The reference points are defined by $100 \%$ saturation of CFC-12 and $p \mathrm{CO}_{2}$ and a ratio of $\Delta / \Gamma=1.0$.

\subsection{Carbon transport estimates}

Table 2 shows the transport estimates of DIC and anthropogenic carbon separated into northward-flowing (positive values) and southward-flowing (negative values) water masses. The northward flux comprises the Atlantic Water of the WSC, the southward flux comprises the Recirculating/Arctic Atlantic Water and the Polar Water of the EGC. The mean flux of deep water layers below $840 \mathrm{~m}$ was taken to be $0 \mathrm{~Sv}$ and therefore not considered for this estimate. Furthermore, any net flux below $1500 \mathrm{~m}$ would not change the anthropogenic carbon inventory of the Nordic Seas or the Arctic Ocean due to the homogeneous distribution of anthropogenic carbon at these depths. The depth range between
840 and $1500 \mathrm{~m}$ might contribute to either the Arctic or the Nordic Seas reservoir but it is still an enclosed basin-basin interaction.

The northward flux transports $3592 \pm 2612$ (mean \pm standard deviation) of DIC and $78 \pm 57 \mathrm{Tg} \mathrm{Cyr}^{-1}$ of anthropogenic carbon into the Arctic Ocean. This inflow is exceeded by an outflow of $2852 \pm 1549 / 67 \pm 36 \mathrm{Tg} \mathrm{C} \mathrm{yr}^{-1}$ by Recirculating and Arctic Atlantic Water and $1118 \pm$ $639 / 23 \pm 13 \mathrm{Tg} \mathrm{C} \mathrm{yr}^{-1}$ by Polar Water. The carbon transport uncertainties are relatively high and there is a lack of water transport data on the Greenland shelf region, e.g., Belgica Bank. Thus we cannot decide with great confidence whether more anthropogenic carbon is transported into or out of the Arctic region through the Fram Strait. 


\subsection{Uncertainties}

We showed that neither the IG-TTD nor linear combinations of the model can describe the tracer age relationships between CFC-12 and $\mathrm{SF}_{6}$ in the Fram Strait. This means that either the models are not suitable to describe the prevailing ventilation pattern or that there are other reasons which lead to the specific concentration ratios. Here we focused on the second case, which incorporates the assumptions that the tracer age relationships are related to different saturation states of the transient tracers and, furthermore, that the simple IG-TTD model can describe the ventilation processes of all water masses in the Fram Strait.

The uncertainties of our approach thus correspond to the chosen shape of the IG-TTD, i.e., the unity ratio of $\Delta / \Gamma=$ 1.0 , and the uncertainties of the measurement precision of the transient tracers and apparent transient tracers (see Sect. 3.6 above). Further uncertainties are related to processes which influence the gas exchange and thus affect the boundary conditions of the tracers. This includes the important yet rarely investigated impact of sea ice cover, sea ice formation and sea ice melting processes, as well as bubble effects during heavy wind conditions, see discussion in Sect. 3.6. The flux estimates are based on transient tracer and DIC data of the ARK-XXVII/1 cruise which only show the specific distribution pattern during June/July 2012 and thus neglect any interannual variabilities of the parameters. The determination of the preformed alkalinity highly depends on the used method. Here we used the linear relationship between surface alkalinity and salinity, which is a commonly used method. However, other authors recommend the use of alkalinity-salinity data from the subsurface layer (Vazquez-Rodriguez et al., 2012) or the surface temperature and salinity dependencies (Lee et al., 2006).

The transport estimates are complicated by the fact that the flow field in the Fram Strait is dominated by small-scale features. The Rossby radius is $4-6 \mathrm{~km}$ which means that the mooring spacing is only able to fully resolve the mesoscale near the shelf break in the WSC. Otherwise, eddies may be aliased between the moorings. The velocities in the recirculation area in the center of the Fram Strait are mostly westward (Beszczynska-Möller et al., 2012) and thus along the mooring array line. Therefore, the meridional velocities in the center of the Fram Strait are only the small residuals of much larger zonal velocities. As a result, the finite accuracy and precision of the current direction measurements has a big impact on the meridional exchanges. Additionally, at depth the flow is topographically steered, but the topographic features are not fully resolved. Interannual variations are also neglected here, but they are small (Beszczynska-Möller et al., 2012). The exchange flow across the Fram Strait below $840 \mathrm{~m}$ (sill depth of Greenland-Scotland Ridge) is assumed to be $0 \mathrm{~Sv}$ for the present purpose.
Table 2. Flux estimates of DIC and anthropogenic carbon in the Fram Strait in 2012. Positive values describe poleward fluxes into the Arctic Ocean.

\begin{tabular}{lrrr}
\hline & Volume (Sv) & \multicolumn{2}{c}{ Transport $\left(\mathrm{Tg} \mathrm{C} \mathrm{yr}^{-1}\right)$} \\
\cline { 3 - 4 } & & DIC & $\begin{array}{r}\text { Anthropogenic } \\
\text { carbon }\end{array}$ \\
\hline AW & $4.4( \pm 3.2)$ & $3592( \pm 2612)$ & $78( \pm 57)$ \\
RAW/AAW & $-3.5( \pm 1.9)$ & $-2852( \pm 1549)$ & $-67( \pm 36)$ \\
PW & $-1.4( \pm 0.8)$ & $-1118( \pm 639)$ & $-23( \pm 13)$ \\
\hline$\Sigma$ & -0.5 & -378 & -12 \\
\hline
\end{tabular}

\section{Conclusions}

Measurements of the transient tracers $\mathrm{CFC}-12$ and $\mathrm{SF}_{6}$ along $78^{\circ} 50^{\prime} \mathrm{N}$ in the Fram Strait in 2012 show specific characteristics of the different water masses. The tracer age relationship between both tracers can be separated into two major sets. One set describes the tracer age relationship of water masses of Atlantic origin as well as deep water masses, the other describes water masses of Arctic origin. We assumed that the different tracer age relationships are due to different saturation effects on the tracers during water mass formation and still-existing offsets of the $\mathrm{SF}_{6}$ concentrations caused by the deliberate tracer release experiment in the Greenland Sea in 1996. The CFC-12 data were saturation corrected by applying the model output of Shao et al. (2013). The corrected data were then used to back-calculate theoretical $\mathrm{SF}_{6}$ data based on the IG-TTD, which then provided the excess concentrations of $\mathrm{SF}_{6}$. The largest excess concentrations of $0.5-$ $0.8 \mathrm{fmol} \mathrm{kg}^{-1}$ were found for the intermediate layer between 500 and $1600 \mathrm{~m}$.

The anthropogenic carbon content was estimated using the IG-TTD and saturation-corrected CFC-12 data in the ocean interior (depths below $100 \mathrm{~m}$ ) and $\mathrm{SF}_{6}$ in the surface layer. The Atlantic Water and Recirculating Atlantic Water is characterized by anthropogenic carbon concentrations of $50-55$ and the Polar Surface Water by concentrations of $40-$ $45 \mu \mathrm{mol} \mathrm{kg}{ }^{-1}$. Maximum concentrations of $35-40 \mu \mathrm{mol} \mathrm{kg}{ }^{-1}$ in the intermediate layer can be found at $1-3^{\circ} \mathrm{W}$. Deep water layers show decreasing concentrations with increasing depth from 35 down to $\sim 10 \mu \mathrm{mol} \mathrm{kg}{ }^{-1}$. According to the different anthropogenic carbon concentrations of the fluxes through the Arctic Ocean gateways, i.e., with higher inflow concentrations than outflow concentrations, the Arctic Ocean can be considered a net carbon sink.

The transport estimates through the Fram Strait are characterized by high uncertainties, so we only focused on the boundary currents, namely the WSC and EGC. The mean current velocity data obtained by a mooring array at $78^{\circ} 50^{\prime} \mathrm{N}$ between 2002 and 2010 suggest a mean northward flux of $4.4( \pm 3.2) \mathrm{Sv}$ of Atlantic Water (WSC) and a mean southward flux of $3.5( \pm 1.9) \mathrm{Sv}$ of Recirculating/Arctic Atlantic 
Water and 1.4 $( \pm 0.8) \mathrm{Sv}$ of Polar Water (EGC). The net transport of anthropogenic carbon by the boundary currents is estimated to $-12 \mathrm{Tg} \mathrm{C} \mathrm{yr}^{-1}$, i.e., a net outflow of the Arctic Ocean. However, the high uncertainties of the overall flux data in the Fram Strait inhibit any statements about dominating shares of DIC and anthropogenic exports or imports to the Arctic Ocean.

The theory of saturation effects on transient tracers requires more targeted experiments and data acquisition from high latitudes to be proven or rejected. However, this approach should not contradict the assumptions on complex ventilation patterns but should rather contribute to a better understanding and analysis of the dynamic processes in polar ocean regions. Estimates of carbon transport are very important for predicting future changes in the global carbon cycle and measuring their impact on the global climate, both of which require continuous improvement and, even more importantly, the critical questioning of existing scientific methods.

Acknowledgements. This work was supported by the Deutsche Forschungsgemeinschaft (DFG) in the framework of the priority program "Antarctic Research with comparative investigations in Arctic ice areas" by the following grant to T. Tanhua and M. Hoppema: Carbon and transient tracers dynamics: A bi-polar view on Southern Ocean eddies and the changing Arctic Ocean (TA 317/5, HO 4680/1). Partial support to T. Tanhua and M. Hoppema was received from EU FP7 project CARBOCHANGE "Changes in carbon uptake and emissions by oceans in a changing climate" (European Community's 7th Framework Programme, grant agreement no. 264879). We are grateful to the Alfred-Wegener-Institut for participation in Polarstern cruise ARK-XXVII/1. We are happy to acknowledge the great support by the captain and crew of Polarstern, the chief scientist and the expedition team. Special thanks goes to Boie Bogner for his technical support during the ARK-XXVII/1 cruise.

The article processing charges for this open-access

publication were covered by a Research

Centre of the Helmholtz Association.

Edited by: A. Sterl

\section{References}

Beszczynska-Möller, A.: The expedition of the research vessel Polarstern to the Arctic in 2012 (ARK-XXVII/1), Rep. Pol. Mar. Res., 660, 1-78, 2013.

Beszczynska-Möller, A. and Wisotzki, A.: Physical oceanography during POLARSTERN cruise ARK-XXVII/1, Alfred Wegener Institute, Helmholtz Center for Polar and Marine Research, Bremerhaven, doi:10.1594/PANGAEA.801791, 2012.

Beszczynska-Möller, A., Fahrbach, E., Schauer, U., and Hansen, E.: Variability in Atlantic water temperature and transport at the entrance to the Arctic Ocean, 1997-2010, ICES J. Mar. Sci., 69, $852-863,2012$
Bullister, J. L. and Wisegarver, D. P.: The shipboard analysis of trace levels of sulfur hexafluoride, chlorofluorocarbon-11 and chlorofluorocarbon-12 in seawater, Deep-Sea Res. Pt. I, 55, 1063-1074, 2008.

de Steur, L., Hansen, E., Mauritzen, C., Beszczynska-Möller, A., and Fahrbach, E.: Impact of recirculation on the East Greenland Current in Fram Strait: Results from moored current meter measurements between 1997 and 2009, Deep-Sea Res., 92, 26-40, 2014.

Dickson, A., Sabine, C., and Chrisitan, J.: Guide to Best Practices for Ocean $\mathrm{CO}_{2}$ Measurements, 2007.

Eakins, B. W. and Sharman, G. F.: Volumes of the World's Ocean from ETOPO1, NOAA National Geophysical Data Center, http: //ngdc.noaa.gov/mgg/global/etopo1_ocean_volumes.html, 2010.

Fahrbach, E., Meincke, J., Österhus, S., Rohardt, G., Schauer, U., Tverberg, V., and Verduin, J.: Direct measurements of volume transports through Fram Strait, Polar Res., 20, 217-224, 2001.

Hall, T. M. and Plumb, R. A.: Age as a diagnostic of stratospheric transport, J. Geophys. Res., 99, 1059-1070, 1994.

Huhn, O., Rhein, M., Hoppema, M., and van Heuven, S.: Decline of deep and bottom water ventilation and slowing down of anthropogenic carbon storage in the Weddell Sea, 1984-2011, DeepSea Res. Pt. I, 76, 66-84, 2013.

Jeansson, E., Olsen, A., Eldevik, T., Skjelvan, I., Omar, A. M., Lauvset, S. K., Nilsen, J. E., Bellerby, R. G. J., Johannessen, T., and Falck, E.: The Nordic Seas carbon budget: Sources, sinks, and uncertainties, Glob. Biogeochem. Cy., 25, 4, doi:10.1029/2010GB003961, 2011.

Johnson, K. M., Wills, K. D., Butler, D. B., Johnson, W. K., and Wong, C. S.: Coulometric total carbon dioxide analysis for marine studies: maximizing the performance of an automated gas extraction system and coulometric detector, Mar. Chem., 44, 167-187, 1993.

Johnson, K. M., Dickson, A. G., Eischeid, G., Goyet, C., Guenther, P., Key, R. M., Millero, F. J., Purkerson, D., Sabine, C. L., Schottle, R. G., Wallace, D. W. R., Wilke, R. J., and Winn, C. D.: Coulometric total carbon dioxide analysis for marine studies: assessment of the quality of total inorganic carbon measurements made during the US Indian Ocean $\mathrm{CO}_{2}$ Survey 1994-1996, Mar. Chem., 63, 21-37, 1998.

Jutterström, S. and Jeansson, E.: Anthropogenic carbon in the East Greenland Current, Prog. Oceanogr., 78, 29-36, 2008.

Karcher, M., Smith, J. N., Kauker, F., Gerdes, R., and Smethie, W. M.: Recent changes in Arctic Ocean circulation revealed by iodine-129 observations and modeling, J. Geophys. Res. Oceans, 117, C8, doi:10.1029/2011JC007513, 2012.

Kurtz, N. T., Markus, T., Farrell, S. L., Worthen, D. L., and Boisvert, L. N.: Observations of recent Arctic sea ice volume loss and its impact on ocean-atmosphere energy exchange and ice production, J. Geophys. Res.-Oceans, 116, C4 doi:10.1029/2010JC006235, 2011.

Kwok, R., Cunningham, G. F., Wensnahan, M., Rigor, I., Zwally, H. J., and Yi, D.: Thinning and volume loss of the Arctic Ocean sea ice cover: 2003-2008, J. Geophys. Res.-Oceans, 114, C7, doi:10.1029/2009JC005312, 2009.

Law, C. S., Watson, A. J., and Liddicoat, M. I.: Automated vacuum analysis of sulphur hexafluoride in seawater: derivation of the atmospheric trend (1970-1993) and potential as a transient tracer, Mar. Chem., 48, 57-69, 1994 
Lee, K., Tong, L. T., Millero, F. J., Sabine, C. L., Dickson, A. G., Goyet, C., Park, G., Wanninkhof, R., Feely, R. A., and Key, R. M.: Global relationships of total alkalinity with salinity and temperature in surface waters of the worlds oceans, Geophys. Res. Lett., 33, 19, doi:10.1029/2006GL027207, 2006.

Liang, J.-H., Deutsch, C., McWilliams, J. C., Baschek, B., Sullivan, P. P., and Chiba, D.: Parameterizing bubble-mediated airsea gas exchange and its effect on ocean ventilation, Global Biogeochem. Cy., 27, 894-905, 2013.

MacGilchrist, G. A., Naveira Garabato, A. C., Tsubouchi, T., Bacon, S., Torres-Valdes, S., and Azetsu-Scott, K.: The Arctic Ocean carbon sink, Deep-Sea Res. Pt. I, 86, 39-55, 2014.

Marnela, M., Rudels, B., Olsson, K. A., Anderson, L. G., Jeansson, E., Torres, D. J., Messias, M.-J., Swift, J. H., and Watson, A. J.: Transports of Nordic Seas water masses and excess SF6 through Fram Strait to the Arctic Ocean, Prog. Oceanogr., 78, 1, doi:10.1016/j.pocean.2007.06.004., 2007.

Marnela, M., Rudels, B., Houssais, M.-N., Beszczynska-Möller, A., and Eriksson, P. B.: Recirculation in the Fram Strait and transports of water in and north of the Fram Strait derived from CTD data, Ocean Sci., 9, 499-519, doi:10.5194/os-9-499-2013, 2013.

Mintrop, L., Pérez, F. F., González-Dávila, M., Santana-Casiano, J. M., and Körtzinger, A.: Alkalinity determination by potentiometry: Intercalibration using three different methods, Cienc. Mar., 26, 23-37, 2000.

Olsson, K. A., Jeansson, E., Tanhua, T., and Gascard, J.-C.: The East Greenland Current studied with CFCs and released sulphur hexafluoride, J. Mar. Sys., 55, 77-95, 2005.

Polyakov, I. V., Beszczynska, A., Carmack, E. C., Dmitrenko, I. A., Fahrbach, E., Frolov, I. E., Gerdes, R., Hansen, E., Holfort, J., Ivanov, V. V., Johnson, M. A., Karcher, M., Kauker, F., Morison, J., Orvik, K. A., Schauer, U., Simmons, H. L., Skagseth, Ø., Sokolov, V. T., Steele, M., Timokhov, L. A., Walsh, D., and Walsh, J. E.: One more step toward a warmer Arctic, Geophys. Res. Lett., 32, 17, doi:10.1029/2005GL023740, 2005.

Rudels, B., Meyer, R., Fahrbach, E., Ivanov, V. V., Österhus, S., Quadfasel, D., Schauer, U., Tverberg, V., and Woodgate, R. A.: Water mass distribution in Fram Strait and over the Yermak Plateau in summer 1997, Ann. Geophys., 18, 687-705, 2000.

Rudels, B., Björk, G., Nilsson, J., Winsor, P., Lake, I., and Nohr, C.: The interaction between waters from the Arctic Ocean and the Nordic Seas north of Fram Strait and along the East Greenland Current: results from the Arctic Ocean-02 Oden expedition, J. Mar. Sys., 55, 1-30, 2005.

Rudels, B., Marnela, M., and Eriksson, P.: Constraints on estimating mass, heat and freshwater transports in the Arctic Ocean: An exercise, in: Arctic-Subarctic Ocean Fluxes, edited by: Dickson, R., Meincke, J., and Rhines, P., Springer Netherlands, doi:10.1007/978-1-4020-6774-7_14, 315-341, 2008.

Rudels, B., Korhonen, M., Budéus, G., Beszczynska-Möller, A., Schauer, U., Nummelin, A., Quadfasel, D., and Valdimarsson, H.: The East Greenland Current and its impacts on the Nordic Seas: observed trends in the past decade, ICES J. Mar. Sci., 69, 841-851, 2012.

Schauer, U. and Beszczynska-Möller, A.: Problems with estimation and interpretation of oceanic heat transport - conceptual remarks for the case of Fram Strait in the Arctic Ocean, Ocean Sci., 5, 487-494, doi:10.5194/os-5-487-2009, 2009.
Schauer, U., Fahrbach, E., Østerhus, S., and Rohardt, G.: Arctic warming through the Fram Strait: Oceanic heat transport from 3 years of measurements, J. Geophys. Res.-Oceans, 109, C6, doi:10.1029/2003JC001823, 2004.

Schauer, U., Beszczynska-Möller, A., Walczowski, W., Fahrbach, E., Piechura, J., and Hansen, E.: Variation of Measured Heat Flow Through the Fram Strait Between 1997 and 2006, in: Arctic-Subarctic Ocean Fluxes, edited by: Dickson, R., Meincke, J., and Rhines, P., Springer Netherlands, doi:10.1007/978-14020-6774-7_4, 65-85, 2008.

Schneider, A., Tanhua, T., Körtzinger, A., and Wallace, D. W. R.: High anthropogenic carbon content in the eastern Mediterranean, J. Geophys. Res., 115, C12, doi:10.1029/2010JC006171, 2010.

Schneider, A., Tanhua, T., Roether, W., and Steinfeldt, R.: Changes in ventilation of the Mediterranean Sea during the past 25 year, Ocean Sci., 10, 1-16, doi:10.5194/os-10-1-2014, 2014.

Shao, A. E., Mecking, S., Thompson, L., and Sonnerup, R. E.: Mixed layer saturations of CFC-11, CFC-12, and SF6 in a global isopycnal model, J. Geophys. Res.-Oceans, 118, 4978-4988, 2013.

Sonnerup, R. E., Mecking, S., and Bullister, J. L.: Transit time distributions and oxygen utilization rates in the Northeast Pacific Ocean from chlorofluorocarbons and sulfur hexafluoride, DeepSea Res. Pt. I, 72, 61-71, 2013.

Stöven, T. and Tanhua, T.: Ventilation of the Mediterranean Sea constrained by multiple transient tracer measurements, Ocean Sci., 10, 439-457, doi:10.5194/os-10-439-2014, 2014.

Stöven, T., Tanhua, T., Hoppema, M., and Bullister, J. L.: Perspectives of transient tracer applications and limiting cases, Ocean Sci., 11, 699-718, doi:10.5194/os-11-699-2015, 2015.

Stroeve, J., Serreze, M., Drobot, S., Gearheard, S., Holland, M., Maslanik, J., Meier, W., and Scambos, T.: Arctic Sea Ice Extent Plummets in 2007, Eos, T. Am. Geophys. Un., 89, 13-14, 2008.

Tanhua, T., Bulsiewicz, K., and Rhein, M.: Spreading of Overflow Water from the Greenland to the Labrador Sea, Geophys. Res. Lett., 32, 10, doi:10.1029/2005GL0227700, 2005.

Tanhua, T., Waugh, D. W., and Wallace, D. W. R.: Use of $\mathrm{SF}_{6}$ to estimate anthropogenic $\mathrm{CO}_{2}$ in the upper ocean, J. Geophys. Res., 113, 2156-2202, 2008.

Tans, P. and Keeling, R.: Full Mauna Loa $\mathrm{CO}_{2}$ record, NOAA/ESRL, www.esrl.noaa.gov/gmd/ccgg/trends/, 2015.

Tsubouchi, T., Bacon, S., Naveira Garabato, A. C., Aksenov, Y., Laxon, S. W., Fahrbach, E., Beszczynska-Möller, A., Hansen, E., Lee, C. M., and Ingvaldsen, R. B.: The Arctic Ocean in summer: A quasi-synoptic inverse estimate of boundary fluxes and water mass transformation, J. Geophys. Res.-Oceans, 117, C1, doi:10.1029/2011JC007174, 2012.

van Heuven, S., Pierrot, D., Rae, J. W. B., Lewis, E., and Wallace, D. W. R.: MATLAB Program Developed for $\mathrm{CO}_{2}$ System Calculations. ORNL/CDIAC-105b. Carbon Dioxide Information Analysis Center, Oak Ridge National Laboratory, US Department of Energy, Oak Ridge, Tennessee, doi:10.3334/CDIAC/otg.CO2SYS_MATLAB_v1.1, 2011.

Vazquez-Rodriguez, M., Padin, X. A., Pardo, P. C., Rios, A. F., and Perez, F. F.: The subsurface layer reference to calculate preformed alkalinity and air-sea $\mathrm{CO}_{2}$ disequilibrium in the Atlantic Ocean, J. Mar. Sys., 94, 52-63, 2012.

Vellinga, M., Dickson, B., and Curry, R.: The Changing View on How Freshwater Impacts the Atlantic Meridional Overturn- 
ing Circulation, in: Arctic-Subarctic Ocean Fluxes, edited by: Dickson, R., Meincke, J., and Rhines, P., Springer Netherlands, doi:10.1007/978-1-4020-6774-7_13, pp. 289-313, 2008.

von Appen, W.-J., Schauer, U., Hattermann, T., and BeszczynskaMöller, A.: Seasonal cycle of mesoscale instability of the West Spitsbergen Current, J. Phys. Oceanogr., in revision, 2015a.

von Appen, W.-J., Schauer, U., Somavilla, R., Bauerfeind, E., and Beszczynska-Möller, A.: Exchange of warming deep waters across Fram Strait, Deep-Sea Res., 103, 86-100, 2015 b.

Wadley, M. R. and Bigg, G. R.: Impact of flow through the Canadian Archipelago and Bering Strait on the North Atlantic and Arctic circulation: An ocean modelling study, Quart. J. Roy. Meteorol. Soc., 128, 2187-2203, 2002.

Watson, A. J., Messias, M., Fogelqvist, E., van Scoy, K. A., Johannessen, T., Oliver, K. I. C., Stevens, D. P., Rey, F., Tanhua, T., Olsson, K. A., Carse, F., Simonsen, K., Ledwell, J. R., Jansen, E., Cooper, D. J., Kruepke, J. A., and Guilyardi, E.: Mixing and convection in the Greenland Sea from a tracer-release experiment, Nature, 401, 902-904, 1999.
Waugh, D. W., Vollmer, M. K., Weiss, R. F., Haine, T. W. N., and Hall, T. M.: Transit time distributions in Lake Issyk-Kul, Geophys. Res. Lett., 29, 84-1-84-4, 2002.

Waugh, D. W., Hall, T. M., and Haine, T. W. N.: Relationships among tracer ages, J. Geophys. Res., 108, C5, doi:10.1029/2002JC001325, 2003.

Waugh, D. W., Haine, T. W. N., and Hall, T. M.: Transport times and anthropogenic carbon in the subpolar North Atlantic Ocean, Deep-Sea Res. Pt. I, 51, 1475-1491, 2004.

Waugh, D. W., Hall, T. M., McNeil, B. I., Key, R., and Matear, R. J.: Anthropogenic $\mathrm{CO}_{2}$ in the oceans estimated using transit time distributions, Tellus B, 58, 376-389, 2006. 